\title{
MENINGKATKAN PEMAHAMAN GRADIEN DENGAN MENGGUNAKAN MODEL PEMBELAJARAN CONTEXTUAL TEACHING AND LEARNING PADA SISWA KELAS VIII MTS NEGERI 2 KOTA SEMARANG
}

\author{
WAHYU SULISTYANINGRUM \\ MTs Negeri 2 Kota Semarang \\ e-mail: wahyusulistyaningrum72@gmail.com
}

\begin{abstract}
ABSTRAK
Penelitian ini dilaksanakan karena penulis melihat hasil ulangan peserta yang masih rendah di bidang pelajaran Matematika Kelas VIIIC pada semester satu tahun 2021/2022 dengan Kompetensi Dasar : Menemukan gradien (kemiringan garis) pada persamaan garis lurus, serta peserta didik mendapatkan nilai kurang dari Kriteria Ketuntasan Minimal (KKM) yaitu 73,00. Dengan latar belakang tersebut, penulis (guru) mengadakan penelitian dengan tujuan supaya siswa dapat meningkatkan pemahaman gradien dalam persamaan garis lurus di kelas VIIIC MTs Negeri 2 Kota Semarang dengan menggunakan model pembelajaran CTL (Contextual Teaching and Learning). Penulis memilih model pembelajaran ini karena mpembelajaran CTL lebih efektif karena meningkatkan pemahaman siswa dengan mengaitkan materi pembelajaran dengan konteks kehidupan sehari-hari. Model pembelajaran CTL ini juga melatih siswa untuk mampu berkonsentrasi dalam memahami gradien dalam persamaan garis lurus. Penelitian diadakan di kelas VIIIC MTs Negeri 2 Kota Semarang, dengan menerapkan 3 siklus. Berdasarkan hasil pengamatan menunjukkan peningkatan keaktifan siswa diikuti dengan hasil belajar siswa. Hal ini menunjukkan bahwa pendekatan kontekstual layak untuk digunakan sebagai salah satu sumber belajar bagi siswa.
\end{abstract}

Kata Kunci: Gradien Persamaan Garis Lurus, Model Pembelajaran CTL

\section{ABSTRACT}

This research was carried out because the authors saw that the results of the participants' test results were still low in Mathematics for Class VIIIC in the first semester of 2021/2022 with Basic Competencies: Finding gradients (slopes of lines) in straight-line equations, and students getting scores less than the Minimum Completeness Criteria. (KKM) is 73.00. With this background, the authors (teachers) conducted research with the aim that students could improve their understanding of gradients in straight-line equations in class VIIIC MTs Negeri 2 Semarang City by using the CTL (Contextual Teaching and Learning) learning model. The author chose this learning model because CTL learning is more effective because it increases students' understanding by linking learning materials to the context of everyday life. This CTL learning model also trains students to be able to concentrate on understanding gradients in straight line equations. The research was conducted in class VIIIC of MTs Negeri 2 Semarang City, by applying 3 cycles. Based on the results of observations showed an increase in student activity followed by student learning outcomes. This shows that the contextual approach is feasible to be used as a learning resource for students.

Keywords: Straight Line Equation Gradient, CTL Learning Model

\section{PENDAHULUAN}

Kurikulum 2013 edisi revisi mata pelajaran matematika menekankan kemampuan pemahaman sebuah konsep karena dibutuhkan konsentrasi dan fokus yang tinggi dalam mengerjakan latihan soal. Umumnya siswa memiliki pemahaman dan ketelitian yang rendah pada saat latihan soal matematika. Contoh pemahaman yang dituntut oleh kurikulum berdasarkan Kompetensi Dasarnya yaitu : Menemukan gradien dalam persamaan garis lurus. Kompetensi dasar inilah siswa kelas VIIIC MTs Negeri 2 Kota Semarang masih mendapatkan nilai yang cukup rendah dibandingkan pada kompetensi dasar lainnya. Hasil belajar siswa hanya mencapai nilai rata-rata adalah $66,03 \%$ dengan $48,39 \%$ siswa yang mencapai ketuntasan 
dengan nilai minimal 73,00. Hasil tersebut masih di bawah standar. Melihat hasil yang rendah pada materi tertentu, maka peneliti selaku guru di MTs Negeri 2 Kota Semarang, merasa tergugah untuk memperbaiki proses pembelajaran sehingga diharapkan dapat mencapai hasil yang diharapkan. Hal ini sesuai dengan Aritonang (2008) bahwa guru perlu melakukan penelitian guna meningkatkan minat dan motivasi belajar siswa, hal tersebut berpengaruh terhadap hasil belajar siswa.

Metode pembelajaran yang tepat merupakan salah satu cara untuk mengoptimalkan hasil belajar siswa dalam pelajaran matematika. Metode pembelajaran yang hanya mengandalkan buku teks sebagai pusat pembelajaran mengakibatkan kurang maksimalnya hasil belajar siswa (Permatasari dan Muslim, 2014). Guru dituntut aktif berinovasi dalam proses pembelajaran dan meninggalkan cara lama dalam kegiatan pembelajaran (Geni dkk, 2020). Metode pembelajaran terkini secara interaktif diperlukan untuk memuat materi interaktif sehingga pengetahuan dan informasi yang diterima siswa tidak sebatas hafalan (Sutirjo dan Manik, 2005). Guru juga perlu memiliki strategi yang tepat dalam setiap proses pembelajaran (Khoirudin dkk, 2013). Guru dapat memanfaatan media dalam pelajaran matematika sehingga dapat meningkatkan minat dan rasa ingin tahu siswa dalam proses pembelajaran (Siamy dkk, 2018). Berdasarkan masalah tersebut, penulis sebagai guru tergugah untuk melakukan pengembangkan media pembelajaran menggunakan model pembelajaran Kontekstual (Contextual Teaching and Learning).

Pembelajaran dengan model kontekstual (Contextual Teaching and Learning). merupakan salah satu strategi dalam proses pembelajaran yang melibatkan siswa secara penuh untuk menemukan materi yang dipelajari yang dapat dihubungkan dengan situasi dalam kehidupan nyata (Siamy dkk, 2018). Selain itu, pendekatan kontekstual mendorong siswa untuk menghubungkan materi yang telah dipelajari dengan situasi kehidupan nyata sehingga dapat diterapkan pada kehidupan mereka (Hobri dkk, 2018). Dengan adanya strategi tersebut diharapkan siswa yang menganggap mata pelajaran sulit dan membosankan akan lebih termotivasi dalam proses pembelajaran. Oleh karena itu, model pembelajaran dengan pendekatan kontekstual cocok diterapkan pada mata pelajaran matematika karena lebih menekankan kepada proses keterlibatan siswa secara penuh untuk menemukan materi yang dipelajari dengan situasi kehidupan nyata dalam hal ini menemukan kemiringan (gradien) garis lurus yang diterapkan dalam kehidupan nyata.

Tujuan penelitian ini yaitu mendeskripsikan proses pelaksanaan pembelajaran menggunakan model pembelajaran kontekstual (Contextual Teaching and Learning) pada siswa kelas VIIIC di MTs Negeri 2 Kota Semarang tahun ajaran 2021/2022. Manfaat penelitian ini bagi siswa yaitu meningkatnya keaktifan siswa pada pelaksanaan pembelajaran diikuti dengan peningkatan hasil belajar siswa. Manfaat bagi guru yaitu diperolehnya pengetahuan nyata tentang pembelajaran model kontekstual dalam meningkatkan keaktifan siswa dan hasil belajar siswa.

\section{METODE PENELITIAN}

Penelitian ini dilaksanakan di MTs Negeri 2 Kota Semarang Tahun Pelajaran 2021/2022 jangka waktu tiga bulan pada bulan September sampai Oktober 2021. Subjek penelitian yaitu siswa kelas VIIIC MTs Negeri 2 Kota Semarang yang berjumlah 31 siswa. Faktor yang hendak diteliti dalam penelitian ini yaitu tingkat pemahaman siswa dilihat dari faktor siswa : (a) keaktifan siswa dalam mengikuti proses belajar mengajar; dan (b) peningkatan hasil belajar siswa berupa kemampuan afektif dan kognitif dalam mengerjakan soal matematika.

\section{Teknik Analisis Data}

Tingkat pemahaman siswa dicerminkan berdasarkan hasil keaktifan siswa dan hasil belajar siswa yang meningkat. Untuk menilai hasil keaktifan siswa dalam mengikuti proses belajar mengajar dibedakan berdasarkan kategori : (a) Baik jika keaktifan ++; (b) Cukup jika keaktifan +; dan (c) Kurang jika keaktifan-Dikategorikan siswa aktif yaitu siswa yang memiliki kategori "cukup" dan "baik". Penilaian hasil belajar siswa diperoleh dari pengujian dan 
penilaian yang berupa nilai kemampuan kognitif diklasifikasikan berdasarkan nilai KKM yaitu 73. Siswa yang mendapatkan nilai 73 atau lebih dikategorikan "tuntas" sedangkan siswa yang mendapatkan nilai dibawah 73 dikategorikan "belum tuntas".

\section{Teknik Pengumpulan Data}

Metode pengumpulan data dilakukan melalui empat tahapan dengan uraian sebagai berikut:

a. Pra Siklus adalah pengumpulan data keaktifan siswa dan data nilai hasil belajar sebelum diadakannya pelatihan.

b. Siklus I adalah pengumpulan data keaktifan siswa dan nilai hasil belajar siswa pada pelatihan I.

c. Siklus II adalah pengumpulan data keaktifan siswa dan nilai hasil belajar siswa pada pelatihan II.

d. Siklus III adalah pengumpulan data keaktifan siswa dan nilai hasil belajar siswa pada pelatihan III.

\section{Desain Penelitian}

Penelitian ini dilaksananakan dalam tiga siklus yang masing-masing melalui empat tahap, yaitu: tahap perencanaan, tahap pelaksanan, tahap pengamatan/pengumpulan data/insrumen, dan tahap refleksi. Berikut ini gambaran tahapan pelaksanaan penelitian secara grafik siklus

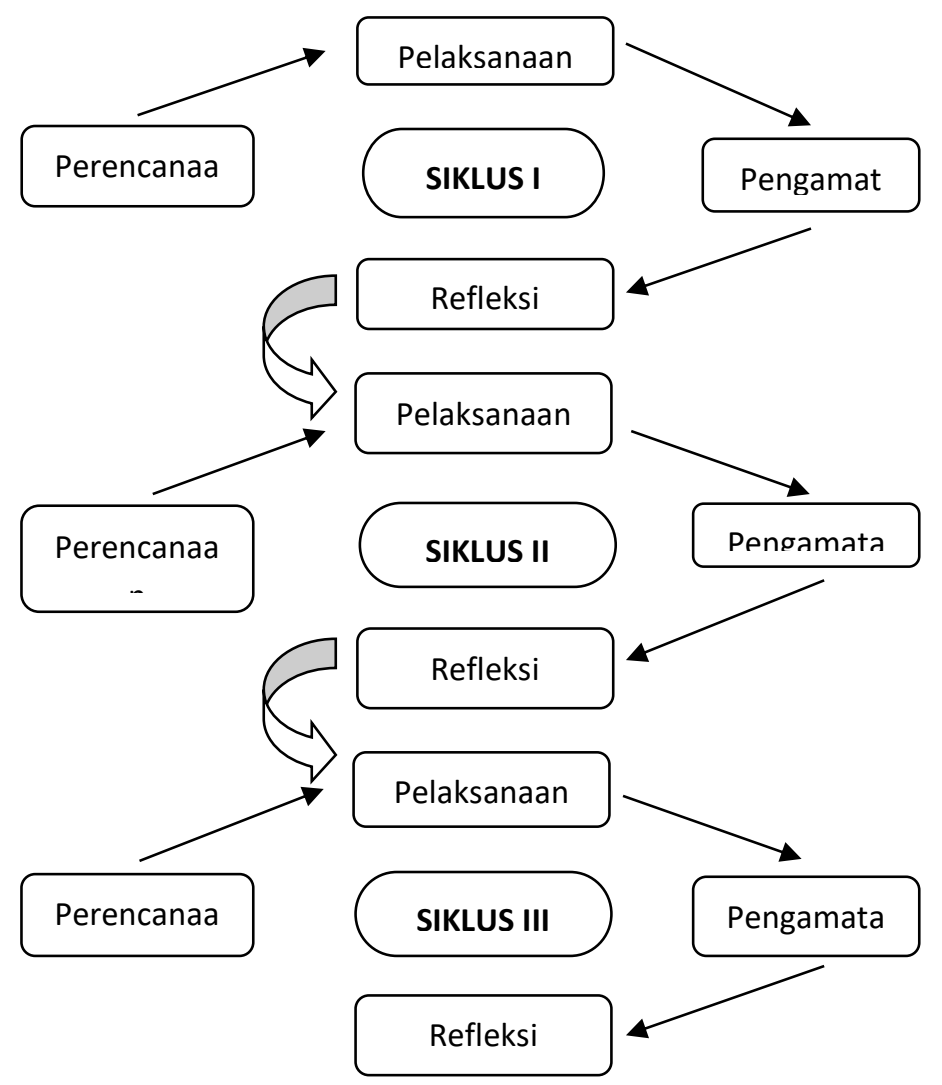

Gambar 1. Siklus Penelitian Tindakan Kelas

\section{HASIL DAN PEMBAHASAN}

\section{Deskripsi Kondisi Awal}

Dari data kondisi awal/pra siklus keaktifan siswa didalam proses pembelajaran Matematika diketahui siswa kategori kurang 54,84\%, cukup 35,48 \% dan baik 9,68 \%, sehingga keaktifan sebesar $45,16 \%$. Data kondisi awal/pra siklus hasil belajar siswa didalam proses pembelajaran Matematika sebesar 48,39\%, yang memiliki siswa tuntas KKM 16 (48,39\%) siswa dan tidak tuntas KKM $16(51,61 \%)$ siswa. Rendahnya keaktifan siswa dan hasil belajar 
menunjukkan bahwa kurangnya pemahaman siswa mengenai gradien garis lurus. Oleh karena itu, data tersebut digunakan sebagai standar awal siswa sebelum dilakukan tindakan pembelajaran kelas.

\section{Hasil Penelitian}

Hasil penelitian menunjukkan bahwa, model pembelajaran kontekstual pada setiap siklus memiliki dampak positif yaitu meningkatkan pemahaman gradien garis lurus pada siswa, yang dapat dilihat dari keaktifan siswa diikuti dengan hasil belajar siswa. Perbandingan kriteria keaktifan siswa menggunakan model pembelajaran kontekstual pada setiap siklus dapat dilihat pada

Tabel 1. Perbandingan Kriteria keaktifan Siswa Pra Siklus, Siklus I, Siklus II dan Siklus III

\begin{tabular}{|c|l|c|c|c|c|}
\hline No. & Kriteria & Pra Siklus & \multicolumn{1}{l|}{ Siklus I } & \multicolumn{1}{l|}{ Siklus II } & \multicolumn{1}{l|}{ Siklus III } \\
\hline 1. & Kurang & $54,84 \%$ & $48,39 \%$ & $32,26 \%$ & $0 \%$ \\
\hline 2. & Cukup & $35,48 \%$ & $41,94 \%$ & $35,48 \%$ & $45,16 \%$ \\
\hline 3. & Baik & $9,68 \%$ & $9,68 \%$ & $32,26 \%$ & $54,84 \%$ \\
\hline
\end{tabular}

Dikategorikan siswa aktif yaitu siswa yang memiliki kategori "cukup" dan "baik". Berikut ini perbandingan keaktifan siswa pada Pra Siklus, Siklus I, Siklus II dan Siklus III disajikan pada Diagram 2.

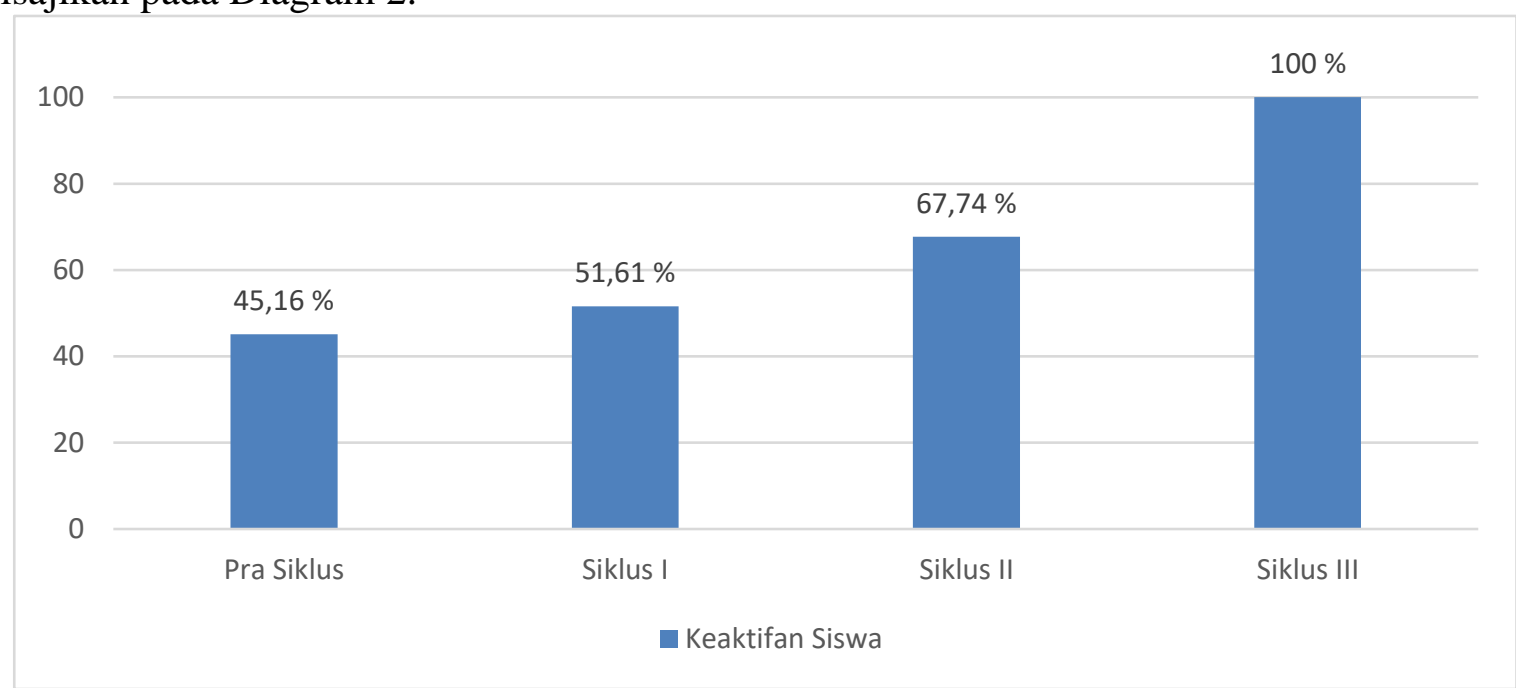

Gambar 2. Diagram Perbandingan Keaktifan Siswa antar Siklus.

Berikut ini perbandingan hasil belajar siswa antar siklus berdasarkan KKM disajikan pada Tabel 2.

Tabel 2. Perbandingan hasil belajar siswa antar Siklus berdasarkan KKM

\begin{tabular}{|c|c|c|c|c|c|}
\hline No & Uraian & Pra Siklus & Siklus I & Siklus II & Siklus III \\
\hline 1. & $\begin{array}{c}\text { Jumlah siswa yang } \\
\text { tuntas / sesuai KKM }\end{array}$ & $\begin{array}{c}15 \\
(48,39 \%)\end{array}$ & $\begin{array}{c}21 \\
(67,74 \%)\end{array}$ & $\begin{array}{c}23 \\
(74,19 \%)\end{array}$ & $\begin{array}{c}31 \\
(100 \%)\end{array}$ \\
\hline 2. & $\begin{array}{c}\text { Jumlah siswa yang } \\
\text { tidak tuntas }\end{array}$ & $\begin{array}{c}16 \\
(51,61 \%)\end{array}$ & $\begin{array}{c}10 \\
(32,26 \%)\end{array}$ & $\begin{array}{c}8 \\
(25,81 \%)\end{array}$ & $\begin{array}{c}0 \\
(0 \%)\end{array}$ \\
\hline
\end{tabular}


Berikut ini hasil belajar siswa antar siklus berdasarkan KKM disajikan pada Diagram 3.

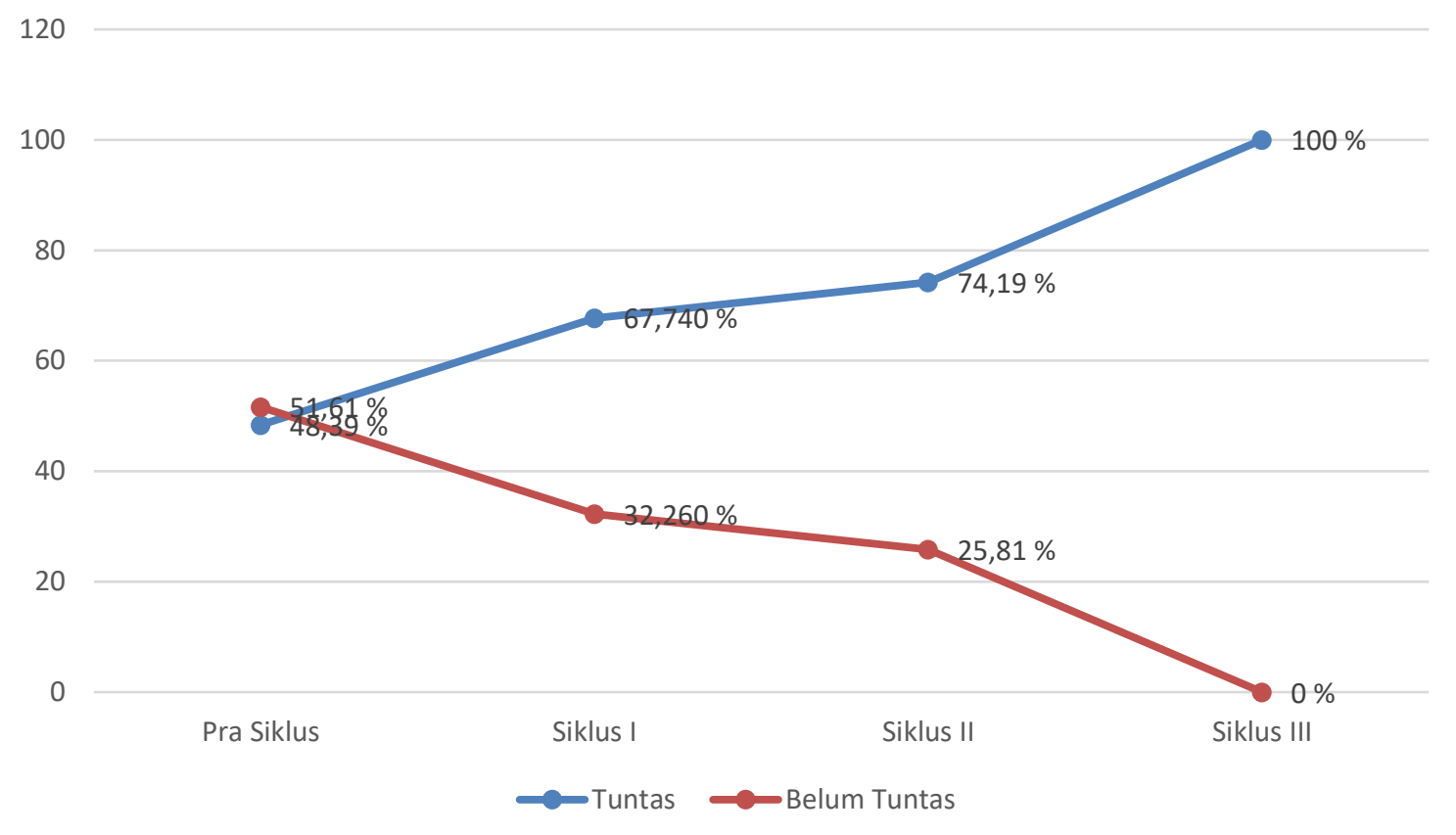

Gambar 3. Diagram Hasil Belajar Siswa antar Siklus Berdasarkan KKM

Berikut ini perbandingan hasil belajar siswa Pra Siklus, Siklus I, Siklus II dan Siklus III disajikan pada Tabel 3 .

Tabel 3. Perbandingan hasil belajar siswa Pra Siklus, Siklus I, Siklus II dan Siklus III

\begin{tabular}{|c|c|c|c|c|c|}
\hline No & Uraian & Pra Siklus & Siklus I & Siklus II & Siklus III \\
\hline 1. & Jumlah Nilai & 2123 & 2379 & 2419 & 2573 \\
\hline 2. & Rata-rata & 66,03 & 74,16 & 75,29 & 80,25 \\
\hline 3. & Ketuntasan Belajar & $48,39 \%$ & $67,74 \%$ & $74,19 \%$ & $100 \%$ \\
\hline
\end{tabular}

Berikut ini perbandingan ketuntasan belajar siswa antar siklus disajikan pada Diagram 4

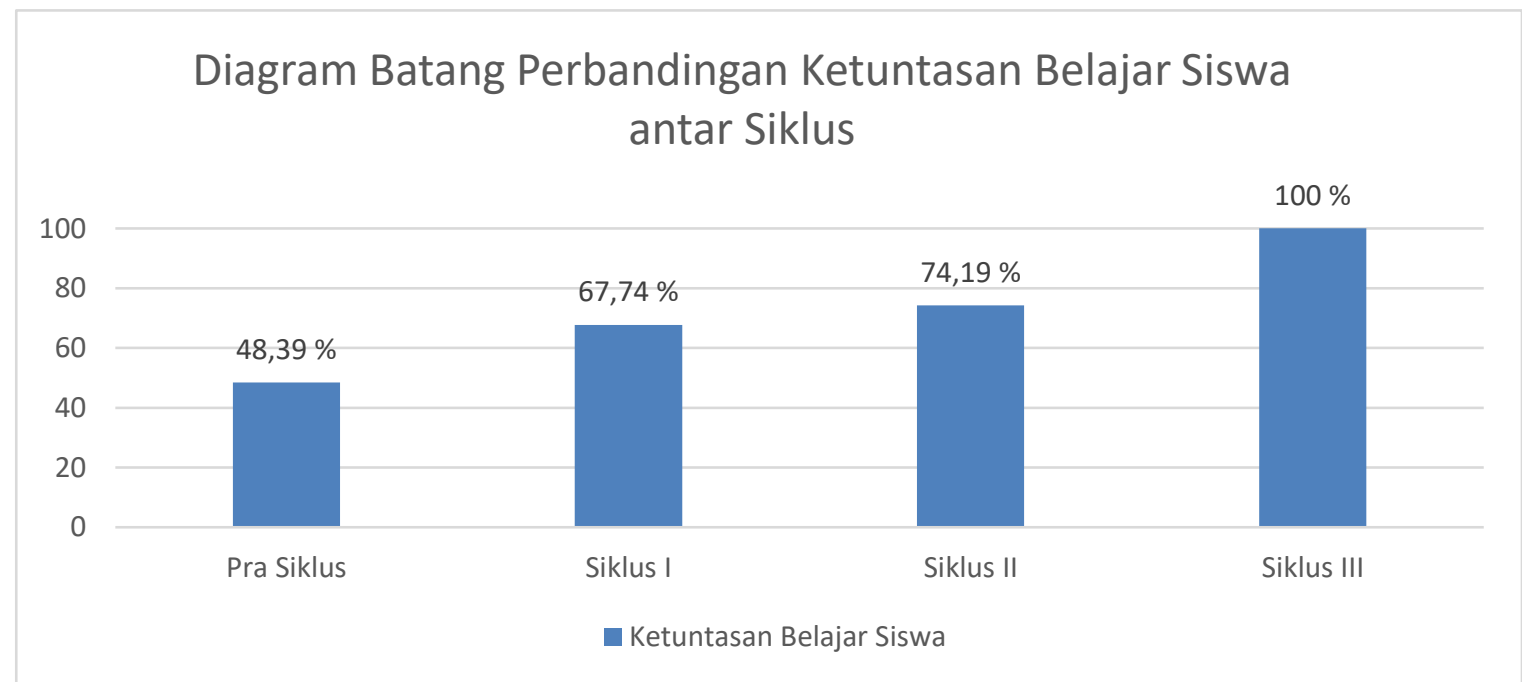

Gambar 4. Diagram Perbandingan Ketuntasan Belajar Siswa antar Siklus.

\section{Pembahasan}

Berdasarkan Tabel 1. diatas terlihat adanya peningkatan pemahaman siswa terhadap gradien garis lurus dengan menggunakan métode kontekstual. Peningkatan keaktifan siswa dari Pra Siklus ke Siklus I sebesar 6,45 \% diikuti dengan peningkatan hasil belajar siswa dari Pra 
Siklus ke Siklus I sebesar 19,35 \%. Peningkatan tersebut disebabkan adanya interaksi akibat penggunaan model kontekstual, dimana siswa mampu menghubungkan materi yang telah dipelajari dengan situasi kehidupan sehari-hari. Pada akhir siklus I dilakukan tes untuk mengukur hasil belajar siswa. Setelah dilakukan pemeriksaan pekerjaan siswa diperoleh nilai rata-rata sebesar 74,16 dan persentase ketuntasan belajar sebesar 67,74\%. Hal menunjukan adanya peningkatan sebesar $19,35 \%$. Peningkatan ini disebabkan siswa memiliki tingkat pemahaman materi yang meningkat.

Adanya peningkatan keaktifan siswa dari Siklus I ke Siklus II sebesar 16,13\% diikuti dengan peningkatan hasil belajar siswa dari Siklus I ke Siklus II sebesar 6,45 \%. Hal ini sesuai dengan pendapat Fadhilaturrahmi (2017) bahwa dengan metode pendekatan kontekstual mampu meningkatkan motivasi siswa dalam mengikuti proses pembelajaran sehingga efektif dalam meningkatkan keaktifan dan hasil belajar siswa. Pada akhir siklus II dilaksanakan ulangan harian untuk mengetahui peningkatan pemahaman materi gradien garis lurus pada siswa. Prosedur dan tehnik pelaksaan penilaian dilaksanakan seperti pada siklus I.

Pada Siklus II ke Siklus III terjadi peningkatan keaktifan siswa sebesar 32,26 \% diikuti dengan peningkatan hasil belajar siswa sebesar $25,81 \%$. Hasil tersebut menunjukkan adanya peningkatan pemahaman dan pengetahuan siswa terhadap materi gradien garis lurus setelah diterapkannya model kontekstual, karena siswa memiliki kesempatan untuk menghubungkan materi gradien garis lurus dengan contoh pada kehidupan sehari-hari sehingga siswa dapat menyelesaikan soal dengan yakin dan memiliki pemahaman yang baik. Hal ini sesuai dengan Nuryadi (2014) bahwa timbulnya pengaruh baik pada siswa adalah tolak ukur bahwa proses pembelajaran telah berjalan dengan baik.

Berdasarkan Tabel 2. diatas dapat diketahui bahwa terjadi peningkatan hasil belajar siswa berdasarkan KKM. Siklus I tuntas KKM 21 (67,74 \%) siswa, siklus II tuntas $23(74,19$ $\%)$ siswa dan siklus III tuntas $31(100 \%)$ siswa. Hal tersebut menunjukkan hasil belajar siswa dengan metode kontekstual berhasil diterapkan dan diterima dengan baik oleh siswa. Hal ini sesuai dengan Siamy dkk (2018) bahwa variasi proses belajar mengajar diperlukan untuk meningkatkan minat siswa sehingga kegiatan pembelajaran tidak membosankan.

\section{KESIMPULAN}

Kesimpulan dari penelitian ini yaitu pembelajaran model kontekstual yang dilaksanakan di kelas VIIIC Semester Ganjil MTs Negeri 2 Kota Semarang mampu meningkatkan motivasi siswa dalam pelajaran Matematika khususnya materi gradien garis lurus dengan menerapkan 3 siklus yaitu Pra Siklus, Siklus I, Siklus II, dan Siklus III. Pembelajaran model kontekstual berhasil diterapkan diketahui dari adanya peningkatan nilai keaktifan siswa dan hasil belajar siswa.

Aktifitas keaktifan siswa dan kemampuan aspek kognitif siswa sudah memenuhi kriteria diatas nilai KKM 73 pada indikator yang ditentukan. Adanya peningkatan perbandingan nilai keaktifan siswa pada Pra Siklus, Siklus I, Siklus II, dan Siklus III yaitu 45,16 \%, 51,61 \%, 67,74 $\%$ dan $100 \%$ serta peningkatan perbandingan nilai hasil belajar siswa siswa pada Pra Siklus, Siklus I, Siklus II, dan Siklus III yaitu 48,39 \%, 67,74 \%, 74,19\% dan $100 \%$.

Berdasarkan kesimpulan diatas maka penulis menyarankan penggunaan pembelajaran model kontekstual sangat membantu siswa dalam belajar Matematika karena siswa mampu mengaitkan materi yang diberikan dengan kehidupan sehari-hari. Berdasarkan hal ini penulis menyarankan para guru untuk menggunakan pembelajaran model kontekstual sehingga dapat dikembangkan pada materi lain atau mata pelajaran lain.

\section{DAFTAR PUSTAKA}

Aritonang, K. T. (2008). Minat dan motivasi dalam meningkatkan hasil belajar siswa. Jurnal pendidikan penabur, 7(10), 11-21. 
Fadhilaturrahmi. (2017). Peningkatan Hasil Belajar Siswa Pada Materi Jaring-Jaring Balok dan Kubus dengan Pendekatan Contextual Teaching and Learning (CTL) Siswa Kelas IV SDN 05 Air Tawar Barat. Jurnal Basicedu, 1(1), 1-9.

Geni, K. H. Y. W., Sudarma, I. K., \& Mahadewi, L. P. P. (2020). Pengembangan Multimedia Pembelajaran Interaktif Berpendekatan CTL Pada Pembelajaran Tematik Siswa Kelas IV SD. Jurnal Edutech Undiksha, 8(2), 1-16.

Hobri., dkk. (2018). High-Order Thinking Skill in Contextual Teaching and Learning of Mathematics Based on Lesson Study for Learning Community. International Journal of Engineering \& Technology, 7(3), 1576-1580.

Khoirudin, N., Wahyuningsih, D., \& Rahardjo, D. T. (2013). Pengembangan Media Pembelajaran dengan Menggunakan Aplikasi Mindjet MindManager 9 untuk Siswa SMA pada Pokok Bahasan Alat Optik. Jurnal Pendidikan Fisika, 1(1).

Nuryadi, N. (2014). Keefektifan Pendekatan CTL dan PPM Pembelajaran Matematika Metode GTG Ditinjau Keaktifan dan Prestasi Siswa. PYTHAGORAS: Jurnal Pendidikan Matematika, 9(1), 22-30.

Permatasari, S. W. E., \& Muslim, S. (2014). Implementasi Model Pembelajaran Contextual Teaching and Learning (CTL) Pada Standar Kompetensi Dasar Memasang Instalasi Penerangan Listrik di SMKN 7 Surabaya. Jurnal Pendidikan Teknik Elektro, 3(2), 4753.

Siamy, L., Farida, F., \& Syazali, M. (2018). Media Belajar Matematika Berbasis Multimedia Interaktif dengan Pendekatan Contextual Teaching and Learning. Desimal: Jurnal Matematika, 1(1), 113-117.

Sutirjo dan Sri Istuti Mamik. 2005. Pembelajaran Efektif dalam Kurikulum 2006. Malang : Bayumedia Publishing. 